\title{
Review
}

\section{Nosemosis Prevention and Control}

 \\ Marcella Milito $^{1, *}$, Sofia Croppi ${ }^{1}$ and Mariano Higes ${ }^{2}(\mathbb{D}$
}

1 Istituto Zooprofilattico Sperimentale del Lazio e della Toscana "M. Aleandri", Apiculture, Honey Bee Productions and Diseases Laboratory, OIE Collaborating Centre for Good Beekeeping Management Practices and Biosecurity Measures in the Apiculture Sector, FAO Reference Centre for Animal Health and Food Security-Discipline Apiculture, Health and Biosecurity, Via Appia Nuova 1411, 00178 Rome, Italy; giovanni.formato@izslt.it (G.F.); jorge.rivera@um.es (J.R.-G.); jernej.bubnic@kis.si (J.B.); sofia.croppi@gmail.com (S.C.)

2 Laboratorio de Patología Apícola, Centro de Investigación Apícola y Agroambiental de Marchamalo, Instituto Regional de Investigación y Desarrollo Agroalimentario y Forestal de Castilla-La Mancha (IRIAF), Consejería de Agricultura de la Junta de Comunidades de Castilla-La Mancha, 19180 Marchamalo, Spain; rmhernandez@jccm.es (R.M.-H.); mhiges@jccm.es (M.H.)

3 Instituto de Recursos Humanos para la Ciencia y la Tecnología (INCRECYT-ESF/EC-FSE), Fundación Parque Científico y Tecnológico de Castilla—La Mancha, 02006 Albacete, Spain

* Correspondence: marcella.milito@izslt.it; Tel.: +39-06-790991

Citation: Formato, G.; Rivera-Gomis, J.; Bubnic, J.; Martín-Hernández, R.; Milito, M.; Croppi, S.; Higes, M. Nosemosis Prevention and Control. Appl. Sci. 2022, 12, 783. https:// doi.org/10.3390/app12020783

Academic Editor: Panos V. Petrakis

Received: 8 November 2021

Accepted: 4 January 2022

Published: 13 January 2022

Publisher's Note: MDPI stays neutral with regard to jurisdictional claims in published maps and institutional affiliations.

Copyright: (C) 2022 by the authors. Licensee MDPI, Basel, Switzerland. This article is an open access article distributed under the terms and conditions of the Creative Commons Attribution (CC BY) license (https:// creativecommons.org/licenses/by/ $4.0 /)$.

\begin{abstract}
Nosemosis is a serious microsporidian disease of adult European honey bees caused by the spore-forming unicellular fungi Nosema apis and Nosema ceranae. In this paper we describe the currently known techniques for nosemosis prevention and control including Good Beekeeping Practices (GBPs) and biosecurity measures (BMBs). Topics such as queen renewal, nosema-resistant bees and hygienic and control methods are described. Strong efforts are currently provided to find more a sustainable solution than the use of antibiotics. So far, it seems that the best way to approach nosemosis is given by an "integrated pest management strategy", which foresees the contemporary application of different, specific GBPs and BMBs.
\end{abstract}

Keywords: nosemosis; prevention; control; Good Beekeeping Practices; biosecurity measures

\section{Introduction}

Nosema spp. are microsporidia responsible for nosemosis of honey bees (Apis mellifera L. and Apis cerana F.). These pathogens are obligate parasites of the epithelial cells of the ventriculus of adult honey bees [1,2] and are spread throughout the world [3,4]. Infection of the bees occurs by the oral ingestion of spore-contaminated honey, pollen or water [5-8]. Other ways of transmission of the spores may be by trophallaxis $[9,10]$, foraging activities on the flowers or cleaning tasks in the colonies [11]. The spores are released in large quantities with the faeces of diseased bees and can be infective for more than one year [12]. So far, three Nosema species have been identified to infect honey bees: N. apis [13], N. ceranae [1] and N. neumanni [14].

$N$. ceranae is a microsporidium firstly isolated in the Asian bee Apis cerana, and then found in Apis mellifera [3,15]. It is currently endemic worldwide [16], as well as the other well-known Nosema species: N. apis [13]. However, in some regions, usually with colder climates, N. apis is still prevalent. N. apis has a low prevalence in Southern Europe [16-19] while N. ceranae is widely present in Southern Europe, specifically in areas with a temperatewarm climate $[3,20]$. N. ceranae infection has important differences with $N$. apis control due to the microsporidium biology and because N. ceranae tends to persist throughout the year [3].

N. apis is responsible for clinical signs of nosemosis type A. Such signs include a high mortality of adult bees and the presence of fecal spotting at the hive entrance due to digestive disorders in adult bees. $N$. ceranae is responsible for clinical signs of nosemosis type C 
that are represented by evident loss of adult population, decrease in honey production and final collapse $[7,21]$. The absence of a clear symptomatology of $N$. ceranae has complicated its distinction from N. apis in Europe [22].

Nosema ceranae has been frequently related to colony losses $[7,23,24]$, even with the possible contribution of trypanosomatids such as Crithidia mellificae and Lotmaria passim [25-28]. $N$. ceranae presence in association with other pathogens such as viruses [29-31] or varroa [32] and contaminants $[33,34]$ has been demonstrated to increase honey bee colony losses.

Recently another Nosema species was identified in Uganda (Africa): N. neumanni [35].

The distribution and pathogenicity of this microsporidium is still under investigation.

This paper aims to give an overview of the main strategies for the prevention and control of nosemosis in order to prevent the previously described damages.

\section{Prevention Methods: Good Beekeeping Practices and Biosecurity Measures}

Good Beekeeping Practices (GBPs) are those integrative activities that beekeepers apply for on-apiary production to attain optimal health for humans, honey bees and the environment [36]. Biosecurity Measures in Beekeeping (BMBs) are all those operational activities implemented by the beekeepers to reduce the risk of introduction and spread of specific honey bee disease agents [37].

The application of the GBPs together with the BMBs, therefore, have a positive effect on colony health and on society in general and at the same time guarantee high production standards [38]. These specific actions should be implemented by beekeepers at the apiary level, with the support of veterinarians or other specialized practitioners, when needed.

Starting from a previous study of the BPRACTICES consortium, a GBPs and BMBs list for Nosemosis prevention has been identified, taking into consideration the OIE and FAO documentation [38] and similar previous works [39].

The list of the good practices and measures to adopt for Nosema spp. can be found in Table 1 and in Boxes 1-3.

Table 1. Good Beekeeping Practices (GBPs) and Biosafety Measures in Beekeeping (BMBs) for Nosema spp.

Buy queens from breeders with stocks free of Nosema spp.

Prevent pollution of artificial water sources with faeces or drowned or dead bees.

Remove and destroy combs with signs of dysentery.

Take samples of forager honey bees (or powder sugar or hive debris) early in autumn or spring for laboratory analysis to diagnose Nosemosis (microscopic examination and PCR).

Adopt a proper pathogen (e.g., V. destructor) control, to ensure a proper balance in the composition of the bee colony (equilibrium of nurse-forager bees).

Treat the colony if percentages of infected bees are higher than $40 \%$, if there are any registered/permitted products in your country against Nosema.

Strengthen and stimulate the colonies in autumn and spring with the administration of stimulant integrators or feed supplements.

Do not reuse combs originating from depopulated or collapsed hives,

Select and breed Nosema-resistant honey bees

Strengthen and stimulate the colonies in autumn and spring with the administration of stimulant integrators composed by vegetal substances/molasses or vitamin integrators.

Disinfect beekeeping tools and equipment between uses: torching (Nosema ceranae spores are inactivated over $60^{\circ} \mathrm{C}$ ); gamma irradiation; fumigation of combs with glacial acetic acid, sodium hydroxide $5 \%$ (caustic soda); sodium hypochlorite $0.5 \%$ (bleach) and ammonium hydroxide $1.65 \%$ (ammonia solution). 
Table 1. Cont.

Do not feed extracted honey or combs with stores (honey or pollen) from Nosema-infested colonies to healthy colonies.

Replace the queens every two years, minimum, except those of high genetic value.

Have only healthy, strong colonies in the apiary,

Keep colonies of new introduction separate from the existing stock for an appropriate period (at least 1 month) to monitor them for diseases and infestations in order to prevent transmission of diseases.

Wintering: perform beehive box maintenance (replace parts or painting and verify the integrity of hive boxes, if needed).

Clean or disinfect (in case of infectious diseases) the hive box before installing new colonies.

Remove beehives with dead colonies as soon as possible.

Renew $30 \%$ of the hive combs every year.

Keep all documents/certificates about the commercial feed used.

Ensure the bees access to safe water sources.

Control varroa infestation levels.

Reduce bee stress (e.g., avoiding unnecessary winter inspections of the hives; limiting the use of the smoker; feeding properly the bees, etc.).

Box 1. Queen renewal.

A very effective method to control $N$. ceranae in field conditions is the queen's replacement, as demonstrated by [40]. Indeed, this biotechnical management is a basic apicultural practice because of the crucial role of the queen in the renewal of the bee population and consequently to replace the bees lost due to the infection, keeping the colony homeostasis. Young queens have a greater egg laying potential, and they produce a higher proportion of uninfected newly hatched bees to compensate for adult bee losses.

To prove it, the authors developed a field study to determine the effect of induced queen replacement on Nosema infections in honey bee colonies, focusing on the measurement of colony strength and honey production. Queen replacement resulted in a remarkable decrease in the rates of Nosema infection, comparable with that induced by fumagillin treatment. Similar observations were made also by [41], who observed that the infection consequences worsen when the age of the queen increases

Box 2. Nosema-resistant bees.

In Denmark, honey bee colonies have been selected for the absence of Nosema infections for decades [42]. This breeding scheme resulted in a honey bee strain in which Nosema infections are rarely found, and individual adult bees showed a high tolerance towards experimental $N$. ceranae infections [43]. More recently, regions that seem to be related with resistance to Nosema were identified. That resistance has been observed due to the capacity of reducing the energetic stress and the better capacity of tissue regeneration in resistant bees and avoiding the reduction of apoptosis caused by Nosema [42,44,45]. 
Box 3. Nosema spore disinfection.

Different disinfection strategies have been evaluated and applied to reduce the viability and potential infectivity of microsporidian parasites, as spores can remain viable for long time periods. In general, microsporidians can be killed by boiling spores for at least $5 \mathrm{~min}$ or applying disinfectants including quaternary ammonium, 70\% ethanol, formaldehyde, phenolic derivatives, hydrogen peroxide, chloramines, sodium hydroxide or amphoteric surfactants [44]. In relation to honey bee microsporidian pathogens, differences on thermotolerance between species have been reported.

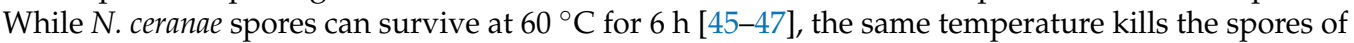
N. apis in 5 min [48].

Surfaces contaminated with $N$. ceranae spores can be effectively disinfected using any of the following products: (i) an ammonia solution, (ii) a sodium hypochlorite solution or (iii) a ready-to-use commercial alcohol-based solution (Mycoplasma OFFTM); therefore, these products are proposed for the disinfection of beekeeping equipment. The usefulness of other products, such as acetic acid, which causes spore destruction, requires further research.

\section{Control Methods}

The availability of control methods specific for nosemosis and the awareness about them may prevent a reduction in vitality or losses of affected colonies [21,24,49-52].

So far, there is a lack of knowledge regarding control methods for nosemosis. Here we classify the Nosema control strategies in antibiotic treatments, organic control methods, (phytotherapeutics, essential oils, bacteria metabolite and organic acids) and RNA-based technologies.

\subsection{Antibiotic Treatments}

Given that honey bees are food-producing animals $[53,54]$, the use of antibiotic treatments in beekeeping should consider the impact on the hive products, mainly in terms of residues [54].

Nosemosis control with antibiotics has been mainly based on fumagillin administration. Depending on the geographical location and colony conditions (e.g., weather, stress, strength, etc.), it is advised to treat infested colonies from once (in autumn during feeding) to twice a year (in autumn and in spring, in the case of severe infections) [55-58]. While the autumn treatment aims to keep the colony alive during the cold season, the spring treatment is focused on improving the health status of adult bees that will be able to properly take care of the next generation of bees that are raised in spring.

While efficacy of fumagillin against N. apis has long since been proven [59], recent evidence indicates that fumagillin is effective against $N$. ceranae in western honey bees too [60]. Nevertheless, the use of fumagillin in heavily infected colonies with N. ceranae did not improve the size or increase the survival rate of colonies during winter, regardless of the dose or administration strategy adopted [61,62]. Moreover, the study carried out by Li et al. (2017) suggested that the elimination of gut bacteria by an antibiotic treatment weakened the immune function and made honey bees more susceptible to Nosema infection.

Treating colonies with $120 \mathrm{mg} /$ colony of fumagillin in four applications (total amount of syrup $250 \mathrm{~mL}$, each application $62.5 \mathrm{~mL}$ ) was effective against depopulation and colony death, although relapses were detectable 4 months after treatment ended [7]. The total amount of active fumagillin ingested by a bee is the key to effectiveness. Administration of fumagillin with sucrose syrup gave better results than with medicated patties, which were not entirely consumed by the bees during field trials [7].

The use of fumagillin is not authorized in Europe due to the lack of a maximum residue limit definition in honey and of a registered veterinary medicine with this active substance. Its use in the EU may be admitted only under exceptional circumstances. Fumagillin is registered for use in Canada to treat Nosema disease. It is available in the commercial product as a salt, dicyclohexylamine (DCH). This chemical contaminant is a potential hazard for human health, as it is five times more toxic than fumagillin according to studies conducted on rats, and it is a genotoxic and oncogenic compound [61]. DCH is significantly more resistant to degradation in honey than fumagillin. Observed half-lives for DCH 
ranged from a minimum of 368 days, when stored at $34^{\circ} \mathrm{C}$ in darkness, to a maximum of 852 days, when stored at $21^{\circ} \mathrm{C}$ in darkness. A maximum half-life of 246 days was observed for fumagillin in samples kept in darkness at a temperature of $21^{\circ} \mathrm{C}$, while the observed half-life of fumagillin was estimated to be 3 days when exposed to light at $21^{\circ} \mathrm{C}$, and complete degradation was observed after 30 days under the same conditions. The stability of $\mathrm{DCH}$, combined with its toxicity, make it an important hazard to be considered regarding hive products for human consumption safety [62].

The effectiveness of commercial product Fumagilin $B^{\circledR}$ showed to be influenced by several factors, such as storage conditions (e.g., temperature and $\mathrm{RH}$ ), dosage, dilution and UV exposure. High temperatures inside the hive can drastically reduce the initial concentration of fumagillin within a few hours.

Moreover, the effect of low fumagillin concentrations were tested. At lower fumagillin concentrations, significantly more pathogenic spores of $N$. ceranae were produced in treated bees than in untreated infected bees. Protein profiles of bees fed with fumagillin confirmed the hypothesis that fumagillin affects bee physiology when administered at concentrations lower than those that are effective against $N$. ceranae. In the case of mixed infections, the prevalence of $N$. ceranae may increase due to the use of fumagillin, replacing $N$. apis, which is more sensitive to the treatment [63].

A novel mass spectrometry allows the determination of traces of fumagillin and its degradation products in honey [7].

As an alternative to fumagillin, in vitro tests performed on the lepidopteran cell line showed that tinidazole and metronidazole can completely inhibit $N$. ceranae infection and were as effective as fumagillin. However, both substances cannot be used for the control of Nosema spp., as they belong to the active ingredients not allowed in the EU (Reg. 37/2010). The use of nitroimidazoles in dairy animals is prohibited in many countries [64].

\subsection{Organic Control Methods}

In Europe, we consider as organic methods the veterinary treatments allowed for organic beekeeping production [65]. A veterinary treatment is defined as "all courses of a curative or preventive treatment against one occurrence of a specific disease" [66].

Organic control methods can be identified with phytotherapeutics, organic acids, essential oils, polysaccharides, bacteria and metabolites. Their frequent common advantages are: their availability in many countries; the low risk for consumers to contaminate bee products; their low toxicity for the environment and the absence of demonstrated resistance of nosema. As a possible disadvantage, they could demonstrate high variability in reducing the infection levels of nosema in bees [21].

\subsubsection{Phytotherapeutics}

Other natural compounds have been tested with promising results in laboratory conditions. Among these are thymol showing a Nosema-inhibiting effect and thymol and resveratrol showing a positive impact in increasing bee longevity [67].

Herbal supplements (with or without $C$ vitamin), have shown to reduce the $N$. ceranae infection levels in affected honey bee colonies enhancing their strength [68] and reducing the winter mortality [69]. Feeds containing Brassica nigra and Eruca sativa, with different amounts of glucosinolates (GSLs), reduced the N. ceranae infection [70]. Additionally, Agaricus blazei extract [71], Andrographis paniculate, Asteraceae (Artemisia dubia, Aster scaber, Helianthus annuus) and Eleuthereococcus senticosus may have a positive effect against nosemosis [69].

Piperine (an alkaloid in the roots of the Piperaceae family) and curcumin (a natural phenol produced by Curcuma longa) are potential candidates regarding antinosemosis therapy too, being able to increase the activity of the antioxidant system in honey bees [69].

Another product derived from plants that have demonstrated activity against $N$. ceranae infection is propolis. This product administrated to bees before or after the Nosema infection reduced significantly mortality, infectivity and infection rates [72]. 
The control of Nosema has also been focused on causing limitations to the gut cell invasion. That is the objective of the phyto-pharmacological preparation of Nozevit, a preparation that includes plant polyphenols, vitamins, minerals and amino acids. Histological studies showed that Nozevit induces the production of mucous from the epithelial layer of treated bees and provides an additional effect of coating the peritrophic membrane to form a firmer envelope that ensures protection from new invasions of Nosema spores [73]. Similar data had been previously observed in field experiments by the reduction of bee count spores [74] and by the reduction in the number of infected house and forager worker honey bees [52], although with lower efficacies than in the fumagillin control hives.

Other tested products such as Nosestat (a.i. Iodine 4 g.-Formic Acid 5 g. in 100 mL. of product), Phenyl salicylate or Vitafeed Gold (extract of Beta vulgaris) gave good results, highly related with low consumption of the different doses by bees in field conditions [21]. Concerning the essential oils, Porrini [75] and Damiani [76] observed significant antiparasitic activity of Laurus nobilis alcoholic extract, similarly, and found that different extracts of the same plant inhibited $N$. ceranae spore development, having the best results with ethanol extracts. More recently, Origanum vulgare and Rosmarinus officinalis alcoholic extracts $(0.7 \%$ $\mathrm{g} / \mathrm{g}$, volatile oils) reduced the number of spores after three consecutive treatments without being related with bee mortality [77]. Bravo [78] found the essential oils of Cryptocarya alba to be effective in controlling $N$. ceranae development in vitro.

\subsubsection{Bacteria and Their Metabolite}

Acetobacteraceae are able to suppress the development of $N$. ceranae reducing the spore load [69].

Porrini [79] obtained good results with a bacterial metabolite and, specifically, surfactin, both in reduction of infectivity and in parasitosis development.

\subsubsection{Organic Acids}

Maggi [80] evaluated the effects of organic acids produced by Lactobacillus johnsonii CRL1647 (lactic acid, phenyl-lactic acid and acetic acid). A reduction on Nosema intensity was observed after two treatments, as well as the enhancement of fumagillin efficiency. No toxic effects were found in vitro, observing an increase of the beehive population and in the size of fat bodies in the bees. It is a clear example of the possibilities of natural new molecules on Nosema control.

Nanetti [81] tested the use of oxalic acid to control N. ceranae both in laboratory and in field conditions. They found that those oral applications interfered with the increase of artificial infections, and that two topical administrations in field conditions decreased the prevalence in the colony, finding a significant difference with untreated colonies and concluding that oxalic acid is a valid substance to be used to control N. ceranae infections.

\subsubsection{Polysaccharides}

The $\beta$-glucans (glucose homopolymers) are known for their immune-modulating impact on different species, including honey bees. The polysaccharide chitosan stimulates the bee immune system, leading to a decrease in the degree of infection with $N$. apis and to increased bee survival [69].

\subsection{Other Control Methods: RNA Interference (RNAi)}

The oral application of double-stranded RNA (dsRNA) in N. ceranae infected bees can activate the immune response, suppress the reproduction of $N$. ceranae and improve honey bees' health status [82]. The results obtained from the use of RNAi technology demonstrated the prospects of its applications in anti-nosemosis therapy, but more research is needed in order to be widely implemented in beekeeping practice [69]. 


\section{Conclusions}

Many different strategies exist to manage nosemosis in honey bees. Good Beekeeping Practices and biosecurity measures provide tools to prevent and control the disease, avoiding its spread among colonies in infected apiaries and also among different apiaries in the same region. Selection of resistant honey bee stock has a great potential among the sustainable solutions.

The use of antibiotic fumagillin is forbidden in some countries and should be passed in favour of more sustainable beekeeping. Its residues in honey bee products pose a serious threat to consumer's health. Many different plant extracts exhibit antinosemosis properties, but their efficacy is low. So far, it seems that the most effective and sustainable solution to prevent and control nosemosis is to adopt different measures (GBPs, BMBs), and combine them in a so called "integrated pest management" strategy. However, further studies must be conducted to determine which methods should be combined and also to determine how and when adopt them to reach the highest possible efficacy.

Author Contributions: Conceptualization, G.F. and M.H.; methodology, M.H., R.M.-H.; writingoriginal draft preparation M.H., J.R.-G., R.M.-H., J.B., G.F., M.M.; writing—review and editing, J.R.-G., G.F., M.H., R.M.-H., S.C.; supervision, M.H., G.F. All authors have read and agreed to the published version of the manuscript.

Funding: This research received no external funding.

Institutional Review Board Statement: Not applicable.

Informed Consent Statement: Not applicable.

Data Availability Statement: Not applicable.

Conflicts of Interest: The authors declare no conflict of interest.

\section{References}

1. Fries, I.; Feng, F.; da Silva, A.; Slemenda, S.B.; Pieniazek, N.J. Nosema ceranae n. sp.(Microspora, Nosematidae), morphological and molecular characterization of a microsporidian parasite of the Asian honey bee Apis cerana (Hymenoptera, Apidae). Eur. J. Protistol. 1996, 32, 356-365. [CrossRef]

2. OIE Terrestrial Manual. Nosemosis of Honey Bees; Chapter 2.2.4. 2013. Available online: https://www.oie.int/en/what-we-do/ standards/codes-and-manuals/terrestrial-manual-online-access/ (accessed on 8 November 2021).

3. Martín-Hernández, R.; Meana, A.; Prieto, L.; Salvador, A.M.; Garrido-Bailón, E.; Higes, M. Outcome of colonization of Apis mellifera by Nosema ceranae. Appl. Environ. Microbiol. 2007, 73, 6331-6338. [CrossRef] [PubMed]

4. Klee, J.; Besana, A.M.; Genersch, E.; Gisder, S.; Nanetti, A.; Tam, D.Q.; Chinh, T.X.; Puerta, F.; Ruz, J.M.; Kryger, P. Widespread dispersal of the microsporidian Nosema ceranae, an emergent pathogen of the western honey bee, Apis mellifera. J. Invertebr. Pathol. 2007, 96, 1-10. [CrossRef] [PubMed]

5. L'Arrivee, J.C.M. Sources of nosema infection. Am. Bee J. 1965, 105, 264.

6. Bailey, L.; Ball, B.V. Nosema Apis Spore Transmission among Honey Bees. In Honey Bee Pathology; Webster, T.C., Ed.; Academy Press: London, UK,, 1991.

7. Higes, M.; Martín-Hernández, R.; Botías, C.; Bailón, E.G.; González-Porto, A.V.; Barrios, L.; Del Nozal, M.J.; Bernal, J.L.; Jiménez, J.J.; Palencia, P.G. How natural infection by Nosema ceranae causes honeybee colony collapse. Environ. Microbiol. 2008, 10, 2659-2669. [CrossRef]

8. Giersch, T.; Berg, T.; Galea, F.; Hornitzky, M. Nosema ceranae infects honey bees (Apis mellifera) and contaminates honey in Australia. Apidologie 2009, 40, 117-123. [CrossRef]

9. Webster, T.C. Nosema apis spore transmission among honey bees. Am. Bee J. 1993, 133, 869-870.

10. Smith, M.L. The honey bee parasite Nosema ceranae: Transmissible via food exchange? PLoS ONE 2012, 7, e43319. [CrossRef]

11. Bailey, L. The infection of the ventriculus of the adult honeybee by Nosema apis (Zander). Parasitology 1955, 45, 86-94. [CrossRef]

12. Fries, I. Nosema apis-A parasite in the honey bee colony. Bee World 1993, 74, 5-19.

13. Zander, E. Tierische parasiten als krankenheitserreger bei der biene. Münchener Bienenztg. 1909, 31, $196-204$.

14. De Graaf, D.C.; Raes, H.; Sabbe, G.; De Rycke, P.H.; Jacobs, F.J. Early development of Nosema apis (Microspora: Nosematidae) in the midgut epithelium of the honeybee (Apis mellifera). J. Invertebr. Pathol. 1994, 63, 74-81. [CrossRef]

15. Higes, M.; Martín, R.; Meana, A. Nosema ceranae, a new microsporidian parasite in honeybees in Europe. J. Invertebr. Pathol. 2006, 92, 93-95. [CrossRef] [PubMed]

16. Fries, I.; Chauzat, M.-P.; Chen, Y.-P.; Doublet, V.; Genersch, E.; Gisder, S.; Higes, M.; McMahon, D.P.; Martín-Hernández, R.; Natsopoulou, M. Standard methods for Nosema research. J. Apic. Res. 2013, 52, 1-28. [CrossRef] 
17. Gajger, I.T.; Vugrek, O.; Grilec, D.; Petrinec, Z. Prevalence and distribution of Nosema ceranae in Croatian honeybee colonies. Vet. Med. 2010, 55, 457-462. [CrossRef]

18. Naudi, S.; Šteiselis, J.; Jürison, M.; Raimets, R.; Tummeleht, L.; Praakle, K.; Raie, A.; Karise, R. Variation in the Distribution of Nosema Species in Honeybees (Apis mellifera Linnaeus) between the Neighboring Countries Estonia and Latvia. Vet. Sci. 2021, 8 , 58. [CrossRef]

19. Papini, R.; Mancianti, F.; Canovai, R.; Cosci, F.; Rocchigiani, G.; Benelli, G.; Canale, A. Prevalence of the microsporidian Nosema ceranae in honeybee (Apis mellifera) apiaries in Central Italy. Saudi J. Biol. Sci. 2017, 24, 979-982. [CrossRef]

20. Fries, I.; Forsgren, E. Undersökning av spridningen av Nosema ceranae i Sverige. Investig. Distrib. Nosema Ceranae Swed. Bitidningen 2008, 107, 26-27.

21. Botías, C.; Martín-Hernández, R.; Meana, A.; Higes, M. Screening alternative therapies to control Nosemosis type C in honey bee (Apis mellifera iberiensis) colonies. Res. Vet. Sci. 2013, 95, 1041-1045. [CrossRef]

22. Chauzat, M.-P.; Jacques, A.; Laurent, M.; Bougeard, S.; Hendrikx, P.; Ribiere-Chabert, M. Risk indicators affecting honeybee colony survival in Europe: One year of surveillance. Apidologie 2016, 47, 348-378.

23. Ravoet, J.; Maharramov, J.; Meeus, I.; De Smet, L.; Wenseleers, T.; Smagghe, G.; De Graaf, D.C. Comprehensive bee pathogen screening in Belgium reveals Crithidia mellificae as a new contributory factor to winter mortality. PLoS ONE 2013,8 , e72443.

24. Bekele, A.Z.; Mor, S.K.; Phelps, N.B.D.; Goyal, S.M.; Armién, A.G. A case report of Nosema ceranae infection in honey bees in Minnesota, USA. Vet. Q. 2015, 35, 48-50. [CrossRef] [PubMed]

25. Schwarz, R.S.; Bauchan, G.R.; Murphy, C.A.; Ravoet, J.; de Graaf, D.C.; Evans, J.D. Characterization of Two Species of Trypanosomatidae from the Honey Bee Apis mellifera: Crithidia mellificae Langridge and McGhee, and Lotmaria passim n. gen., n. sp. J. Eukaryot. Microbiol. 2015, 62, 567-583. [CrossRef]

26. Ravoet, J.; Schwarz, R.S.; Descamps, T.; Yañez, O.; Tozkar, C.O.; Martin-Hernandez, R.; Bartolomé, C.; De Smet, L.; Higes, M.; Wenseleers, T. Differential diagnosis of the honey bee trypanosomatids Crithidia mellificae and Lotmaria passim. J. Invertebr. Pathol. 2015, 130, 21-27. [CrossRef]

27. Vejnovic, B.; Stevanovic, J.; Schwarz, R.S.; Aleksic, N.; Mirilovic, M.; Jovanovic, N.M.; Stanimirovic, Z. Quantitative PCR assessment of Lotmaria passim in Apis mellifera colonies co-infected naturally with Nosema ceranae. J. Invertebr. Pathol. 2018, 151, 76-81. [CrossRef]

28. Tritschler, M.; Retschnig, G.; Yañez, O.; Williams, G.R.; Neumann, P. Host sharing by the honey bee parasites Lotmaria passim and Nosema ceranae. Ecol. Evol. 2017, 7, 1850-1857. [CrossRef]

29. Wick, C.H.; Stanford, M.F.; Zulich, A.W.; Bromenshenk, J.J.; Henderson, C.B.; Deshpande, S.V.; McCubbin, P.E.; Jabbour, R.E Iridescent Virus and Nosema Ceranae Linked to Honeybee Colony Collapse Disorder; Edgewood Chemical Biological Center Aberdeen Proving Ground Md Research and Technology Dir. 2010. Available online: https://apps.dtic.mil/sti/pdfs/ADA53476 7.pdf (accessed on 7 November 2021).

30. Hartmann, U.; Forsgren, E.; Charrière, J.-D.; Neumann, P.; Gauthier, L. Dynamics of Apis mellifera filamentous virus (AmFV) infections in honey bees and relationships with other parasites. Viruses 2015, 7, 2654-2667. [CrossRef]

31. Zheng, H.-Q.; Gong, H.-R.; Huang, S.-K.; Sohr, A.; Hu, F.-L.; Chen, Y.P. Evidence of the synergistic interaction of honey bee pathogens Nosema ceranae and deformed wing virus. Vet. Microbiol. 2015, 177, 1-6. [CrossRef]

32. Mariani, F.; Maggi, M.; Porrini, M.; Fuselli, S.; Caraballo, G.; Brasesco, C.; Barrios, C.; Principal, J.; Martin, E. Parasitic interactions between Nosema spp. and Varroa destructor in Apis mellifera colonies. Zootec. Trop. 2012, 30, 81-90.

33. Chauzat, M.-P.; Martel, A.-C.; Blanchard, P.; Clément, M.-C.; Schurr, F.; Lair, C.; Ribière, M.; Wallner, K.; Rosenkranz, P.; Faucon, J.-P. A case report of a honey bee colony poisoning incident in France. J. Apic. Res. 2010, 49, 113-115. [CrossRef]

34. Wu, J.Y.; Smart, M.D.; Anelli, C.M.; Sheppard, W.S. Honey bees (Apis mellifera) reared in brood combs containing high levels of pesticide residues exhibit increased susceptibility to Nosema (Microsporidia) infection. J. Invertebr. Pathol. 2012, 109, 326-329.

35. Chemurot, M.; De Smet, L.; Brunain, M.; De Rycke, R.; de Graaf, D.C. Nosema neumanni n. sp. (Microsporidia, Nosematidae), a new microsporidian parasite of honeybees, Apis mellifera in Uganda. Eur. J. Protistol. 2017, 61, 13-19. [CrossRef]

36. Rivera-Gomis, J.; Bubnic, J.; Ribarits, A.; Moosbeckhofer, R.; Alber, O.; Kozmus, P.; Jannoni-Sebastianini, R.; Haefeker, W.; Köglberger, H.; Smodis Skerl, M.I.; et al. Good farming practices in apiculture. Rev. Sci. Tech. 2019, 38, 879-890. [CrossRef]

37. Pietropaoli, M.; Ribarits, A.; Moosbeckhofer, R.; Köglberger, H.; Alber, O.; Gregorc, A.; Smodis Skerl, M.I.; Presern, J.; Bubnic, J.; Necati Muz, M.; et al. Biosecurity measures in European beekeeping. Rev. Sci. Tech. Off. Int. Epiz. 2021, 39. Available online: www.oie.int/app/uploads/2021/06/21062021-00179-en-pietropaoli-formato-ang.pdf (accessed on 2 November 2021).

38. Pietropaoli, M.; Formato, G. Good Beekeeping Practices: FAO Practical Manual on How to Identify and Control the Main Diseases of the Honeybee (Apis mellifera); FAO: Rome, Italy, 2020; Available online: https:/ / www.fao.org/policy-support/tools-and-publications/ resources-details/en/c/1393274/ (accessed on 2 November 2021).

39. Pietropaoli, M.; Skerl, M.S.; Cazier, J.; Riviere, M.-P.; Tiozzo, B.; Eggenhoeffner, R.; Gregorc, A.; Haefeker, W.; Higes, M.; Ribarits, A. BPRACTICES project: Towards a sustainable European beekeeping. Bee World 2020, 97, 66-69. [CrossRef]

40. Botías, C.; Anderson, D.L.; Meana, A.; Garrido-Bailón, E.; Martín-Hernández, R.; Higes, M. Further evidence of an oriental origin for Nosema ceranae (Microsporidia: Nosematidae). J. Invertebr. Pathol. 2012, 110, 108-113. [CrossRef]

41. Simeunovic, P.; Stevanovic, J.; Cirkovic, D.; Radojicic, S.; Lakic, N.; Stanisic, L.; Stanimirovic, Z. Nosema ceranae and queen age influence the reproduction and productivity of the honey bee colony. J. Apic. Res. 2014, 53, 545-554. [CrossRef] 
42. Kurze, C.; Le Conte, Y.; Dussaubat, C.; Erler, S.; Kryger, P.; Lewkowski, O.; Müller, T.; Widder, M.; Moritz, R.F.A. Nosema tolerant honeybees (Apis mellifera) escape parasitic manipulation of apoptosis. PLoS ONE 2015, 10, e0140174.

43. Huang, Q.; Kryger, P.; Le Conte, Y.; Moritz, R.F.A. Survival and immune response of drones of a Nosemosis tolerant honey bee strain towards N. ceranae infections. J. Invertebr. Pathol. 2012, 109, 297-302. [CrossRef]

44. Kurze, C.; Mayack, C.; Hirche, F.; Stangl, G.I.; Le Conte, Y.; Kryger, P.; Moritz, R.F.A. Nosema spp. infections cause no energetic stress in tolerant honeybees. Parasitol. Res. 2016, 115, 2381-2388. [CrossRef]

45. Kurze, C.; Dosselli, R.; Grassl, J.; Le Conte, Y.; Kryger, P.; Baer, B.; Moritz, R.F.A. Differential proteomics reveals novel insights into Nosema-honey bee interactions. Insect Biochem. Mol. Biol. 2016, 79, 42-49. [CrossRef] [PubMed]

46. Didier, E.S.; Stovall, M.E.; Green, L.C.; Brindley, P.J.; Sestak, K.; Didier, P.J. Epidemiology of microsporidiosis: Sources and modes of transmission. Vet. Parasitol. 2004, 126, 145-166. [CrossRef]

47. Fenoy, S.; Rueda, C.; Higes, M.; Martín-Hernández, R.; Del Aguila, C. High-level resistance of Nosema ceranae, a parasite of the honeybee, to temperature and desiccation. Appl. Environ. Microbiol. 2009, 75, 6886-6889. [CrossRef]

48. Cantwell, G.E.; Shimanuki, H. The use of heat to control nosema and increase production for the commercial beekeeper. Am. Bee J. 1970, 110, 263.

49. Higes, M.; Martín-Hernández, R.; Garrido-Bailón, E.; González-Porto, A.V.; García-Palencia, P.; Meana, A.; Del Nozal, M.J.; Mayo, R.; Bernal, J.L. Honeybee colony collapse due to Nosema ceranae in professional apiaries. Environ. Microbiol. Rep. 2009, 1, 110-113. [CrossRef]

50. Lodesani, M.; Costa, C.; Besana, A.; Dall'Olio, R.; Franceschetti, S.; Tesoriero, D.; Giacomo, D. Impact of control strategies for Varroa destructor on colony survival and health in northern and central regions of Italy. J. Apic. Res. 2014, 53, 155-164. [CrossRef]

51. Bravo, J.; Carbonell, V.; Valdebenito, J.T.; Figueroa, C.; Valdovinos, C.E.; Martín-Hernández, R.; Higes, M.; Delporte, C. Identificación de Nosema ceranae en la Región de Valparaíso, Chile. Arch. Med. Vet. 2014, 46, 487-491. [CrossRef]

52. Cepero, A.; Ravoet, J.; Gómez-Moracho, T.; Bernal, J.L.; Del Nozal, M.J.; Bartolomé, C.; Maside, X.; Meana, A.; González-Porto, A.V.; de Graaf, D.C. Holistic screening of collapsing honey bee colonies in Spain: A case study. BMC Res. Notes 2014, 7, 649. [CrossRef]

53. Council, E.U. Council Directive 2001/110/EC of 20 December 2001 relating to honey. Off. J. Eur. Communities L 2002, 10, 47-52.

54. Martel, A.-C.; Zeggane, S.; Drajnudel, P.; Faucon, J.-P.; Aubert, M. Tetracycline residues in honey after hive treatment. Food Addit. Contam. 2006, 23, 265-273. [CrossRef]

55. Gochnauer, T.A.; Furgala, B. Chemotherapy of nosema disease; compatibility of fumagillin with other chemicals. Am. Bee J. 1969, 109, 309-311.

56. Wyborn, M.H.; McCutcheon, D.M. A comparison of dry and wet fumagillin treatments for spring nosema disease suppression of overwintered colonies. Am. Bee J. 1987, 127, 207-209.

57. Williams, G.R.; Sampson, M.A.; Shutler, D.; Rogers, R.E.L. Does fumagillin control the recently detected invasive parasite Nosema ceranae in western honey bees (Apis mellifera)? J. Invertebr. Pathol. 2008, 99, 342-344. [CrossRef] [PubMed]

58. Katznelson, H.; Jamieson, C.A. Control of nosema disease of honeybees with fumagillin. Science 1952, 115, 70-71. [CrossRef]

59. Mendoza, Y.; Diaz-Cetti, S.; Ramallo, G.; Santos, E.; Porrini, M.; Invernizzi, C. Nosema ceranae winter control: Study of the effectiveness of different fumagillin treatments and consequences on the strength of honey bee (Hymenoptera: Apidae) colonies. J. Econ. Entomol. 2017, 110, 1-5.

60. Williams, G.R.; Shutler, D.; Rogers, R.E.L. Effects at Nearctic north-temperate latitudes of indoor versus outdoor overwintering on the microsporidium Nosema ceranae and western honey bees (Apis mellifera). J. Invertebr. Pathol. 2010, 104, 4-7.

61. van den Heever, J.P.; Thompson, T.S.; Curtis, J.M.; Ibrahim, A.; Pernal, S.F. Fumagillin: An overview of recent scientific advances and their significance for apiculture. J. Agric. Food Chem. 2014, 62, 2728-2737.

62. van den Heever, J.P.; Thompson, T.S.; Curtis, J.M.; Pernal, S.F. Stability of dicyclohexylamine and fumagillin in honey. Food Chem. 2015, 179, 152-158.

63. Huang, W.-F.; Solter, L.F. Comparative development and tissue tropism of Nosema apis and Nosema ceranae. J. Invertebr. Pathol. 2013, 113, 35-41.

64. Payne, M.A.; Baynes, R.E.; Sundlof, S.E.; Webb, A.I.; Riviere, J.E. Drugs prohibited from extralabel use in food animals. J. Am. Vet. Med. Assoc. 1999, 215, 28-32.

65. Council Regulation (EC) No 834/2007 No 834/2007 of 28 June 2007 on Organic Production and Labelling of Organic Products and Repealing Regulation (EEC) No 2092/OJ L 189, 20.7. 2007. Available online: https:/ / eur-lex.europa.eu/legal-content/EN/ TXT / ?uri=celex\%3A32007R0834 (accessed on 3 November 2021).

66. Commission Regulation (EC) No 889/2008 of 5 September 2008 Laying down Detailed Rules for the Implementation of Council Regulation (EC) No 834/2007 on Organic Production and Labelling of Organic Products with Regard to Organic Production, Labelling and Control. OJ L 250, 18.9. 2008, pp. 1-84. Available online: https://eur-lex.europa.eu/legal-content/EN/TXT/?uri= celex\%3A32008R0889 (accessed on 3 November 2021).

67. Costa, C.; Lodesani, M.; Maistrello, L. Effect of thymol and resveratrol administered with candy or syrup on the development of Nosema ceranae and on the longevity of honeybees (Apis mellifera L.) in laboratory conditions. Apidologie 2010, 41, 141-150. [CrossRef]

68. Shumkova, R.; Balkanska, R.; Koynarski, T.; Hristov, P. Application of the Natural Products NOZEMAT HERB and NOZEMAT HERB PLUS Can Decrease Honey Bee Colonies Losses during the Winter. Diversity 2021, 13, 228. [CrossRef] 
69. Shumkova, R.; Balkanska, R.; Hristov, P. The Herbal Supplements NOZEMAT HERB ${ }^{\circledR}$ and NOZEMAT HERB PLUS ${ }^{\circledR}$ : An Alternative Therapy for N. ceranae Infection and Its Effects on Honey Bee Strength and Production Traits. Pathogens 2021, 10, 234. [CrossRef]

70. Nanetti, A.; Ugolini, L.; Cilia, G.; Pagnotta, E.; Malaguti, L.; Cardaio, I.; Matteo, R.; Lazzeri, L. Seed meals from Brassica nigra and Eruca sativa control artificial Nosema ceranae infections in Apis mellifera. Microorganisms 2021, 9, 949. [CrossRef]

71. Glavinic, U.; Rajkovic, M.; Vunduk, J.; Vejnovic, B.; Stevanovic, J.; Milenkovic, I.; Stanimirovic, Z. Effects of Agaricus bisporus Mushroom Extract on Honey Bees Infected with Nosema ceranae. Insects 2021, 12, 915. [CrossRef]

72. Naree, S.; Ellis, J.D.; Benbow, M.E.; Suwannapong, G. The use of propolis for preventing and treating Nosema ceranae infection in western honey bee (Apis mellifera Linnaeus, 1787) workers. J. Apic. Res. 2021, 60, 686-696. [CrossRef]

73. Gajger, I.T.; Kozaric, Z.; Berta, D.; Nejedli, S.; Petrinec, Z. Effect of the Herbal preparation Nozevict on the mid-gut structure of honeybees (Apis melífera) infected with Nosema sp. Spores. Vet. Med. 2011, 56, 344-351. [CrossRef]

74. Gajger, I.T.; Vugrek, O.; Pinter, L.; Petrinec, Z. "Nozevit patties" treatment of honey bees (Apis mellifera) for the control of Nosema ceranae disease. Apic. Res. 2009, 149, 1053-1056.

75. Porrini, M.P.; Fernández, N.J.; Garrido, P.M.; Gende, L.B.; Medici, S.K.; Eguaras, M.J. In vivo evaluation of antiparasitic activity of plant extracts on Nosema ceranae (Microsporidia). Apidologie 2011, 42, 700-707. [CrossRef]

76. Damiani, N.; Fernández, N.J.; Porrini, M.P.; Gende, L.B.; Álvarez, E.; Buffa, F.; Brasesco, C.; Maggi, M.D.; Marcangeli, J.A.; Eguaras, M.J. Laurel leaf extracts for honeybee pest and disease management: Antimicrobial, microsporicidal, and acaricidal activity. Parasitol. Res. 2014, 113, 701-709. [CrossRef]

77. Radoi, I.; Sapcaliu, A.; Mateescu, C.; Pop, A.; Savu, V. In vitro screening of hydroalcoholic plant extracts to control Nosema apis infection. J. Biotechnol. 2014, 185, S46. [CrossRef]

78. Bravo, J.; Carbonell, V.; Sepúlveda, B.; Delporte, C.; Valdovinos, C.E.; Martín-Hernández, R.; Higes, M. Antifungal activity of the essential oil obtained from Cryptocarya alba against infection in honey bees by Nosema ceranae. J. Invertebr. Pathol. 2017, 149, 141-147. [CrossRef] [PubMed]

79. Porrini, M.P.; Sarlo, E.G.; Medici, S.K.; Garrido, P.M.; Porrini, D.P.; Damiani, N.; Eguaras, M.J. Nosema ceranae development in Apis mellifera: Influence of diet and infective inoculum. J. Apic. Res. 2011, 50, 35-41. [CrossRef]

80. Maggi, M.; Negri, P.; Plischuk, S.; Szawarski, N.; De Piano, F.; De Feudis, L.; Eguaras, M.; Audisio, C. Effects of the organic acids produced by a lactic acid bacterium in Apis mellifera colony development, Nosema ceranae control and fumagillin efficiency. Vet. Microbiol. 2013, 167, 474-483. [CrossRef]

81. Nanetti, A.; Rodriguez-García, C.; Meana, A.; Martín-Hernández, R.; Higes, M. Effect of oxalic acid on Nosema ceranae infection. Res. Vet. Sci. 2015, 102, 167-172. [CrossRef]

82. Badaoui, B.; Fougeroux, A.; Petit, F.; Anselmo, A.; Gorni, C.; Cucurachi, M.; Cersini, A.; Granato, A.; Cardeti, G.; Formato, G.; et al. RNA-sequence analysis of gene expression from honeybees (Apis mellifera) infected with Nosema ceranae. PLoS ONE 2017, 12, e0173438. [CrossRef] 